
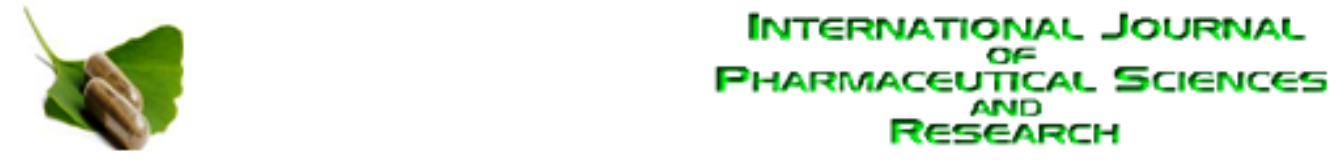

Received on 02 February, 2012; received in revised form 27 May, 2012; accepted 29 May, 2012

\title{
FORMULATION AND EVALUATION OF ALLYLESTRENOL IMMEDIATE RELEASE TABLETS
}

Bishwajit Bokshi and Aparajita Malakar*

Pharmacy Discipline, Life Science School, Khulna University, Khulna-9208, Bangladesh

\author{
Keywords: \\ Immediate release tablets; \\ Allylestrenol; \\ Crosscarmellose sodium; \\ Crosspovidone; \\ Pre gelatinized starch; \\ Sodium starch glycolate
}

Correspondence to Author:

Aparajita Malakar

Pharmacy Discipline, Life Science School Khulna University, Khulna-9208,

Bangladesh

\section{ABSTRACT}

Among the different routes of administration, the oral route of administration continues to be the most preferred route due to various advantages including ease of ingestion, avoidance of pain, versatility and most importantly patient compliance. The different dosage forms include tablets and capsules. Recently immediate release tablets have started gaining popularity and acceptance as a drug delivery system, mainly because they are easy to administer and lead to better patient compliance. The present work involves the formulation development, optimization and in-vitro evaluation of immediate release allylestrenol tablets. To minimize critical process parameters and since allylestrenol is heat sensitive, direct compression method was selected for the formulation of immediate release allylestrenol tablets. Tablets were prepared using cross carmellose sodium, crosspovidone, pre gelatinized starch and sodium starch glycolate as disintegrants. During the course of study it was found that the formula G4 containing sodium starch glycolate as disintegrant exhibited acceptable disintegration time, percentage drug content per tablet and in vitro drug release. So at last it was concluded that immediate release allylestrenol tablets can be prepared using direct compression which met the required specifications.
INTRODUCTION: An immediate release dosage form allows a manufacturer to extend market exclusivity, while offering patients a convenient dosage form or dosage regimen. Immediate release tablets are those tablets which are designed to disintegrate and release their medication with no special rate controlling features, such as special coatings and other techniques 1,2 .

Immediate release and fast dispersing drug delivery system may offer a solution to these problems. Recently immediate release tablets have started gaining popularity and acceptance as a drug delivery system, mainly because they are easy to administer, has quick onset of action is economical and lead to better patient compliance. They are also a tool for expanding markets, extending product life cycles and generating opportunities ${ }^{3,4}$.

Allylestrenol also known as allyloestrenol and allyl estrenol, is a synthetic progestogen sometimes used to prevent threatened miscarriage, recurrent pregnancy loss and premature labor 56 .

In men, it has also been studied as a treatment for benign prostatic hyperplasia, with encouraging results 78 . It is chemically (17ß)-17-(prop-2-en-1-yl)estr-4-en17-ol. A survey of literature has revealed that there is no formulation and evaluation of Allylestrenol tablets. 
The plan of present research is to develop a cost effective allylestrenol immediate release tablets by direct compression method. Direct compression is being studied for its simplicity, cost effectiveness and for its comparatively shorter process. Thus five different formulations were designed to obtain best optimized product.

\section{MATERIALS AND METHODS:}

Materials: Allylestrenol was kindly gifted by Renata Ltd, Bangladesh. Acetonitrile of HPLC grade and Methanol of analytical grade were purchased from E. Merck, Darmstadt, Germany. Lactose was obtained from Reliance Ltd., Mumbai, India. Microcrystalline cellulose (Avicel PH 102) and crosscarmellose sodium was purchased from Ashok Chem-Pharma International, Mumbai, India. Magnesium stearate and sodium starch glycolate were purchased fromAmishi Drugs \& chemicals Private Limited Ahmedabad, India. Pre gelatinized Starch and Crospovidone obtained from Hangzhou Starshine Pharmaceutical Co., Ltd., China, Ludipress was purchased from BASF AG, Ludwigshafen, Germany. Water was deionised and double distilled. All other ingredients used were of analytical grade.

\section{Preparation of Immediate Release Allylestrenol}

Tablets: Allylestrenol and lactose were accurately weighed, geometrically mixed and passed through \#80 mesh and then, microcrystalline cellulose, disintegrants and ludipress were accurately weighed and passed through \#20 mesh. Both mixtures were mixed in rapid mixer granulator for 10 minutes as a dry mixing. Then, colloidal anhydrous silica (aerosil 200) and magnesium stearate was passed through \#40 mesh; added to the mixture in the rapid mixer granulator and mixed for 5 minutes. Then the granules were compressed into tablets using 16 stations rotary compressed machine with punch size $6.0 \mathrm{~mm}$.

\section{Evaluation of Immediate Release Allylestrenol Tablets:}

1. Uniformity of Weight: Individually 20 tablets were weighted at random using Sartorious balance (Model CP- 224 S). Average weight was determined. Determinations were made in triplicate.
Limit - Not more than 2 of the individual masses deviate from the average mass by more than the $7.5 \%$ and none deviates by more than $15 \%{ }^{9}$.

2. Tablet Hardness: Automatic Tablet Hardness Tester (8M, Dr. Schleuniger, Switzerland) was used to determine the crushing strength. 6 tablets were randomly selected from each formulation and the pressure at which each tablet crushed was recorded. Determinations were made in triplicate.

Limit - At least $5 \mathrm{~kg}$.

3. Tablet Friability: 20 tablets of each formulation were weighed and subjected to abrasion by employing a Veego friabilator (VFT-2, India) at $25 \mathrm{rev} / \mathrm{min}$ for $4 \mathrm{~min}$. The tablets were then weighed and compared with their initial weights and percentage friability was obtained. Determination was made in triplicate.

Limit - The weight loss should not be more than $1 \%$.

4. In-vitro Disintegration Test: 6 tablets from each formulation were employed for the test in distilled water at $37^{\circ} \mathrm{C}$ using Tablet Disintegration Tester (Model: VDT-2, Veego, India). The time required for disintegrating the tablet and passing completely through the sieve was recorded.

Limit - Not more than 30 minutes ${ }^{10}$.

5. Pharmaceutical Assay: The instrument used for the study was HPLC (Agilent) having 1100 series HPLC pump, auto sampler equipped with a 100 $\mu l$ sample loop, dual absorbance detector, output signal was monitored and integrated using chemstation software on a XTerra ${ }^{\circledR}$ RP18 column $(150 \times 4.6 \mathrm{~mm}, 5 \mu \mathrm{m}$ particle size). Mobile phase was prepared by mixing HPLC grade water and HPLC grade acetonitrile in the ratio of $20: 80 \mathrm{v} / \mathrm{v}$. The mobile phase was sonicated for $10 \mathrm{~min}$ and filtered through $0.2 \mu \mathrm{m}$ Nylon 6, 6 membrane filter before use. For the preparation of standard stock solution about $20 \mathrm{mg}$ of allylestrenol WS was weighed accurately into a $100 \mathrm{ml}$ volumetric flask and dissolved and diluted to volume with mobile 
phase to obtain a concentration of $200 \mu \mathrm{g} / \mathrm{ml}$. This stock solution was further diluted to 100 $\mathrm{ml}$ with mobile phase to obtain a concentration of $10 \mu \mathrm{g} / \mathrm{ml}$ and filtered through $0.20 \mu \mathrm{m}$ PTFE membrane filter (hydrophilic).

For the preparation of sample solution four tablets equivalent to $20 \mathrm{mg}$ of allylestrenol were weighed and transferred into a $100 \mathrm{ml}$ volumetric flask; $60 \mathrm{ml}$ of mobile phase was added and sonicated with occasional shaking for $15 \mathrm{~min}$. The solution was cooled to room temperature and diluted to volume with the mobile phase. The solution was filtered through Whatman Grade 1 Filter Paper. $5 \mathrm{ml}$ of this solution was diluted to $100 \mathrm{ml}$ with mobile phase.

The final solution was through $0.20 \mu \mathrm{m}$ PTFE membrane filter (hydrophilic). The HPLC analysis was performed on Reversed-Phase High-Performance Liquid ChromatoGraphic System with isocratic elution mode using a mobile phase on $\mathrm{X}^{- \text {Terra }^{\circledR}}{ }^{\circledR}$ RP18 column $(150 \times 4.6 \mathrm{~mm}, 5 \mu \mathrm{m}$ particle size) with 1.5 $\mathrm{ml} / \mathrm{min}$ flow rate at $205 \mathrm{~nm}$ using UV detector. A $100 \mu \mathrm{l}$ volume of above sample solution and standard solution were injected into HPLC and peak areas were measured under optimized chromatographic conditions.

\section{Limit $-90 \%$ to $110 \%$ of the label amount}

6. In-vitro Dissolution Study: The release rate of allylestrenol from immediate release tablets was determined using United State Pharmacopoeia (USP) XXIV dissolution testing apparatus II (Paddle method). The dissolution test was performed using $500 \mathrm{ml}$ of $1.0 \%$ sodium lauryl sulphate in water, at $37 \pm 0.5^{\circ} \mathrm{C}$ and $100 \mathrm{rpm}$. A sample $(10 \mathrm{ml})$ of the solution was withdrawn from the dissolution apparatus 5, 10, 20, 30 and 45 minutes. The samples were replaced with fresh dissolution medium of same quantity. The samples were filtered through a $0.20 \mu \mathrm{m}$ PTFE membrane filter (hydrophilic).
A $100 \mu$ volume of above sample solution was injected into HPLC and peak areas were measured under optimized chromato-graphic conditions as per assay method. Cumulative percentage of drug release was calculated.

Limit - Not less than $75 \%$ of labeled amount of allylestrenol was dissolved in $45 \mathrm{~min}$.

RESULTS AND DISCUSSION: In the present study, various formulations of immediate release allylestrenol tablets were prepared by direct compression. We have chosen to use ludipress because the flow of the material is very good, resulting in the production of tablets with good mechanical resistance and low friability, with an immediate drug release. The use of super disintegrants for preparation of immediate release tablets is highly effective and commercially feasible. These super disintegrants accelerate disintegration of tablets by virtue of their ability to absorb a large amount of water when exposed to an aqueous environment.

The absorption of water results in breaking of tablets and therefore faster disintegration. This disintegration is reported to have an effect on dissolution characteristics as well (Table 2, figure 1). Flow properties of the powder, resistance to particle movement can be judged from the angle of repose. Based on angle of repose it was observed that G4 showed excellent flow properties than the rest of formulations. Carr's index of the prepared blends falls in the range of 10.56 to $18.09 \%$ and Hausner factor values were in the range of 1.12 to 1.23 . Based on the results obtained we can conclude that G4 showed excellent flow.

Disintegration time is very important for immediate release tablets as it assists swallowing and also plays a role in increasing drug absorption, thus promoting bioavailability. Disintegration time of prepared tablets was within the range (Table 3 ). In-vitro drug release study on the prepared tablets were done using $1 \%$ sodium lauryl sulphate in water as medium, at $37 \pm 0.5^{\circ} \mathrm{C}$ from the results it was observed that $\mathrm{G} 4$ showed maximum drug release of $93.20 \%$ which was higher than other formulations (Table 1). 
TABLE 1: FORMULAE FOR PREPARATION OF IMMEDIATE RELEASE ALLYLESTRENOL TABLETS

\begin{tabular}{ccccccc}
\hline \multirow{2}{*}{ SI. No } & Ingredients (mg/tablet) & \multicolumn{5}{c}{ Batch Code } \\
\cline { 3 - 7 } & Allylestrenol & G1 & G2 & G3 & G4 & G5 \\
\hline 1. & Lactose & $5 \mathrm{mg}$ & $5 \mathrm{mg}$ & $5 \mathrm{mg}$ & $5 \mathrm{mg}$ & $5 \mathrm{mg}$ \\
2. & Ludipress & $20 \mathrm{mg}$ & $20 \mathrm{mg}$ & $20 \mathrm{mg}$ & $20 \mathrm{mg}$ & $20 \mathrm{mg}$ \\
3. & $49.5 \mathrm{mg}$ & $49.5 \mathrm{mg}$ & $49.5 \mathrm{mg}$ & $49.5 \mathrm{mg}$ & $49.5 \mathrm{mg}$ \\
4. & Microcrystalline cellulose (Avicel PH 102) & $20 \mathrm{mg}$ & $20 \mathrm{mg}$ & $20 \mathrm{mg}$ & $20 \mathrm{mg}$ & $20 \mathrm{mg}$ \\
5. & Colloidal anhydrous Silica (Aerosil 200) & $1.5 \mathrm{mg}$ & $1.5 \mathrm{mg}$ & $1.5 \mathrm{mg}$ & $1.5 \mathrm{mg}$ & $1.5 \mathrm{mg}$ \\
6. & Magnesium Stearate & $1 \mathrm{mg}$ & $1 \mathrm{mg}$ & $1 \mathrm{mg}$ & $1 \mathrm{mg}$ & $1 \mathrm{mg}$ \\
7. & Croscarmellose sodium & $3 \mathrm{mg}$ & - & - & - & - \\
8. & Crosspovidone & - & $3 \mathrm{mg}$ & - & - & - \\
9. & Pre gelatinized Starch & - & - & $3 \mathrm{mg}$ & - & - \\
10. & Sodium-starch glycolate & - & - & - & $3 \mathrm{mg}$ & - \\
& Total weight & $100 \mathrm{mg}$ & $100 \mathrm{mg}$ & $100 \mathrm{mg}$ & $100 \mathrm{mg}$ & $100 \mathrm{mg}$ \\
\hline
\end{tabular}

TABLE 2: DISSOLUTION PROFILE OF FORMULATIONS

\begin{tabular}{cccccc}
\hline \multirow{2}{*}{ Formulation Code } & \multicolumn{5}{c}{ Time in minutes } \\
\cline { 2 - 6 } & $\mathbf{5}$ & $\mathbf{1 0}$ & $\mathbf{2 0}$ & $\mathbf{3 0}$ & $\mathbf{4 5}$ \\
\hline G1 & $3.56 \%$ & $53.25 \%$ & $70.25 \%$ & $83.52 \%$ & $90.02 \%$ \\
G2 & $3.45 \%$ & $52.45 \%$ & $73.19 \%$ & $84.26 \%$ & $91.45 \%$ \\
G3 & $4.51 \%$ & $49.04 \%$ & $57.26 \%$ & $78.81 \%$ & $88.54 \%$ \\
G4 & $4.65 \%$ & $55.21 \%$ & $74.75 \%$ & $88.25 \%$ & $93.20 \%$ \\
G5 & $1.23 \%$ & $45.18 \%$ & $55.26 \%$ & $75.61 \%$ & $85.23 \%$ \\
\hline
\end{tabular}

TABLE 3: EVALUATION OF POST-COMPRESSION PARAMETERS

\begin{tabular}{|c|c|c|c|c|c|c|c|}
\hline \multirow[b]{2}{*}{$\begin{array}{l}\text { Formulation } \\
\text { Code }\end{array}$} & \multicolumn{7}{|c|}{ Evaluation of post -compression Parameters } \\
\hline & $\begin{array}{l}\text { Hardness of tablets } \\
\left(\mathrm{kg} / \mathrm{cm}^{2}\right)\end{array}$ & $\begin{array}{l}\text { Friability of } \\
\text { tablets (\%) }\end{array}$ & $\begin{array}{l}\text { Weight variation } \\
\text { (mg) } \pm \% \text { deviation }\end{array}$ & $\begin{array}{l}\text { Percent drug content } \\
\text { per tablets }(\%)\end{array}$ & $\begin{array}{l}\text { Drug content } \\
\text { per tablets }(\mathrm{mg})\end{array}$ & $\begin{array}{l}\text { Thickness of } \\
\text { tablets ( } \mathrm{mm} \text { ) }\end{array}$ & $\begin{array}{c}\text { Disintegration } \\
\text { time }(\mathrm{mm})\end{array}$ \\
\hline G1 & 7.3 & 0.787 & $95.95 \mathrm{mg} \pm 1.91 \%$ & 99.46 & 4.973 & 3.08 & 3.54 \\
\hline G2 & 7.4 & 0.845 & $96.02 \mathrm{mg} \pm 1.78 \%$ & 98.98 & 4.949 & 3.07 & 3.55 \\
\hline G3 & 7.7 & 0.595 & $96.54 \mathrm{mg} \pm 1.15 \%$ & 99.86 & 4.993 & 3.09 & 4.17 \\
\hline G4 & 7.5 & 0.540 & $95.24 \mathrm{mg} \pm 1.04 \%$ & 99.98 & 4.999 & 3.08 & 2.55 \\
\hline G5 & 7.9 & 1.267 & $96.09 \mathrm{mg} \pm 2.21 \%$ & 99.24 & 4.962 & 3.07 & 5.42 \\
\hline
\end{tabular}

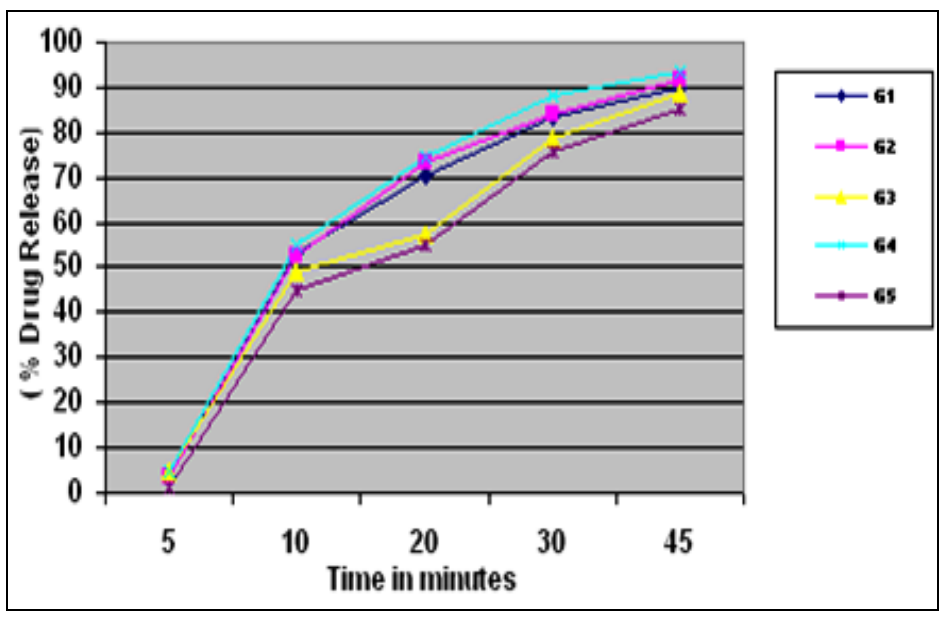

FIGURE 1: DISSOLUTION PROFILE OF FORMULATIONS

CONCLUSION: Considering some important parameters like disintegration time (2.55 $\mathrm{min})$, percentage drug content per tablet $(99.98 \%)$, in vitro drug release (93.20\%) and cost factor G4 containing Sodium-starch glycolate as disintegrant was selected as the best formulation.
It was also observed that direct compression was the best suitable method used for producing immediate release allylestrenol tablets since it is cost effective and less time consuming. Based on all the above considerations these formulas can be subjected for bioavailability studies and if it complies to all the requirement of those studies the same formula can be commercialized.

ACKNOWLEDGEMENTS: The authors would like to express their gratitude to Prof. Dr. Samir Kumar Sadhu, Head of the Department, Pharmacy Discipline, Life Science School, Khulna University, Khulna-9208, Bangladesh, for providing required facilities to carry out this research work.

\section{REFERENCES:}

1. Y.Fu, S.Yang, S.H.Jeong, S.Kimura, K.Park, Crit: Rev Ther Drug Carrier Syst, 2004, 21: 433-476.

2. Shishu, A.Bhatti, Indian Drugs, 2006, 43: 643- 648. 
3. D. Douroumis D, Expert.Opin Drug Deliv, 2007, 4: 417-426.

4. Y. Katsuragi, Y. Sugiura, C.Lee, K.Otsuji, K.Kurihara, Pharm Res, 1995, 12: 658-662.

5. Sean, C.S; Martindale, The complete drug Reference; Thirty-six edition; Pharmaceutical Press, London; 2005.

6. Cortés-Prieto J, Bosch AO, Rocha JA: Allylestrenol: three years of experience with Gestanon in threatened abortion and premature labor. Clinical Therapeutics, 1980; 3: 200-208.

7. Fukuoka H, Ishibashi Y, Shiba T, Tuchiya F, Sakanishi S: Clinical study of allylestrenol (Perselin) on patients with prostatic hypertrophy. Hinyokika Kiyo. Acta Urologica Japonica, 1993; 39 : 679-683.

8. Noguchi K, Takeda M, Hosaka M, Kubota Y: Clinical effects of allylestrenol on patients with benign prostatic hyperplasia (BPH) evaluated with criteria for treatment efficacy in $\mathrm{BPH}$. Hinyokika Kiyo. Acta Urologica Japonica , 2002; 48: 269-273.

9. British Pharmacopoeia 2005, Vol. I, Published by the Stationery Office, London. 2005,697-698.

10. United State Pharmacopoeia-27, NF-22. The United State Pharmacopoeial Convention: Rockville 2004; 2645-2646. 